\title{
Association between SET expression and glioblastoma cell apoptosis and proliferation
}

\author{
KUNYAN HE ${ }^{1}$, LIHONG SHI ${ }^{1}$, TINGTING JIANG ${ }^{1}$, QIANG LI $^{2}$, YAO CHEN $^{1}$ and CHUAN MENG ${ }^{2}$ \\ ${ }^{1}$ Department of Anatomy, Basic Medical and Forensic Medical Institute, Sichuan University; \\ ${ }^{2}$ Department of Neurosurgery, The Third People's Hospital of Chengdu, Chengdu, Sichuan 610041, P.R. China
}

Received March 10, 2016; Accepted July 1, 2016

DOI: $10.3892 / \mathrm{ol} .2016 .4951$

\begin{abstract}
Glioblastoma multiforme (GBM) was one of the first cancer types systematically studied at a genomic and transcriptomic level due to its high incidence and aggressivity; however, the detailed mechanism remains unclear, even though it is known that numerous cytokines are involved in the occurrence and development of GBM. The present study aimed to determine whether the SET gene has a role in human glioblastoma carcinogenesis. A total of 32 samples, including 18 cases of glioma, 2 cases of meningioma and 12 normal brain tissue samples, were detected using the streptavidin-peroxidase method through immunohistochemistry. To reduce SET gene expression in U251 and U87MG cell lines, the RNA interference technique was used and transfection with small interfering (si)RNA of the SET gene was performed. Cell apoptosis was detected by flow cytometry, cell migration was examined by Transwell migration assay and cell proliferation was determined by Cell Counting Kit-8. SET, Bcl-2, Bax and caspase-3 mRNA and protein expression levels were detected by reverse transcription-quantitative polymerase chain reaction and western blot analysis, respectively. Positive protein expression of SET was observed in the cell nucleus, with the expression level of SET significantly higher in glioma tissues compared with normal brain tissue $(\mathrm{P}=0.001)$. Elevated expression of SET was significantly associated with gender $(\mathrm{P}=0.002)$, tumors classified as World Health Organization grade II $(\mathrm{P}=0.031)$, III $(\mathrm{P}=0.003)$ or IV $(\mathrm{P}=0.001)$, and moderately $(\mathrm{P}=0.031)$ or poorly differentiated $(\mathrm{P}=0.001)$ tumors. Compared with the negative and non-treatment
\end{abstract}

Correspondence to: Professor Chuan Meng, Department of Neurosurgery, The Third People's Hospital of Chengdu, 82 Qinglong Road, Chengdu, Sichuan 610041, P.R. China

E-mail: 18081188355@189.cn

Professor Yao Chen, Department of Anatomy, Basic Medical and Forensic Medical Institute, Sichuan University, 17 People's South Road, Chengdu, Sichuan 610041, P.R. China

E-mail: chenyao62@scu.edu.cn

Key words: SET, glioblastoma, cell migration, cell proliferation, cell apoptosis (blank) control cells, SET gene expression was significantly inhibited $(\mathrm{P}=0.006$ and $\mathrm{P}<0.001)$, cell apoptosis was significantly increased $(\mathrm{P}=0.001$ and $\mathrm{P}<0.001)$, cell proliferation was significantly inhibited $(\mathrm{P}=0.002$ and $\mathrm{P}=0.015)$, and cell migration was significantly decreased $(\mathrm{P}=0.001$ and $\mathrm{P}=0.001)$

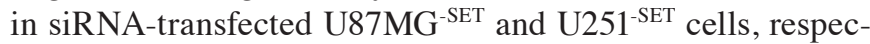
tively. In addition, mRNA and protein expression levels of Bcl-2 were significantly inhibited in $\mathrm{U} 7 \mathrm{MG}^{\text {-SET }}$ and $\mathrm{U} 251^{\text {-SET }}$ cells, while mRNA and protein expression levels of Bax and caspase-3 were significantly increased, compared with the two control groups. Thus, the current data suggests that SET may regulate the proliferation and apoptosis of glioblastoma cells by upregulating Bcl-2, and downregulating Bax and caspase-3.

\section{Introduction}

Glioblastoma multiforme (GBM) is the most prevalent brain and central nervous system (CNS) malignancy, accounting for $45.2 \%$ of primary brain malignancies and CNS tumors, $54 \%$ of all gliomas and $16 \%$ of all primary brain and CNS tumors (1). In addition, the mean annual incidence rate of GBM is 3.19/100,000 population (2). Despite decades of concerted efforts and advances in surgery, radiotherapy and chemotherapy, patients that develop this disease continue to have a poor prognosis. The median survival time is 3 months with no treatment and 1-2 years with treatment from the time of diagnosis (3). The invasive nature of GBM makes it impossible to remove the tumor completely, even with aggressive surgical resection (4). Thus, there is a strong need to understand the molecular basis of this fatal malignancy in order to identify novel targets that can be translated into new diagnostic and therapeutic tools (5). To date, multiple factors, such as Myc (6), EGFR (7), FGL2 (8) and microRNA-145 (4), have been proposed to be involved in the occurrence of GBM. Although considerable progress has been made in research of the molecular mechanism of GBM in recent years, its detailed mechanism remains unknown.

SET, which belongs to the NAP1 family of histone chaperones (9), is a PP2A inhibitor (10) and a 39-kDa phosphoprotein encoded by the SET gene. SET was originally identified as a component of the SET-CAN fusion gene produced by somatic translocation in acute and undifferentiated leukemia (11). It is a multifunctional protein that interacts with other proteins in the regulation of cellular signaling (12). SET has been 
described as an oncogene that regulates important signaling pathways, with SET reported to have roles in inhibiting the DNase activity of tumor suppressor NM23-H1, increasing AP-1 activity, activating MAPK signaling, regulating granzyme B (13) and producing IFN- $\gamma$ in human NK cells. All these functions are involved in SET-regulated cell apoptosis, cell cycle progression and cell mortality (14) through cell processes, such as DNA replication, chromatin remodeling, gene transcription, differentiation and migration (15). Furthermore, SET is overexpressed in various types of cancer, including brain, lung, ovarian, head and neck, and prostate cancer, Wilms' tumor, colorectal adenocarcinoma, and leukemia (16).

In order to understand the detailed mechanism of SET in the occurrence of GBM, immunohistochemistry (IHC) was performed to determine the protein expression level of SET in glioblastoma tissues and normal brain tissues via the streptavidin-peroxidase (SP) method. After SET was silenced with small interfering (si)RNA, flow cytometry, Cell Counting Kit-8 (CCK-8) and Transwell migration assays were performed

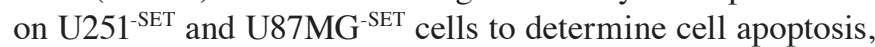
cell proliferation and cell migration, respectively. In addition, reverse transcription-quantitative polymerase chain reaction (RT-qPCR) and western blotting were used to examine mRNA and protein expression levels of Bcl-2, Bax and caspase- 3 in $\mathrm{U} 251^{\text {-SET }}$ and $\mathrm{U}^{2} 7 \mathrm{MG}^{\text {-SET }}$ cells, respectively.

\section{Materials and methods}

Tissue specimens. Human glioblastoma tissues were obtained from 20 patients and normal brain tissues were obtained from 12 patients (including 6 adjacent normal tissues and 6 other patients) that underwent surgery at The Third People's Hospital of Chengdu (Chengdu, China) between April 2012 and January 2015. Sample acquisition was approved by the Medical Research Ethics Committee of The Third People's Hospital of Chengdu and written informed consent was obtained from all patients. Clinicopathological parameters are indicated in Table I.

Antibodies. The primary antibodies used for western blotting were as follows: Rabbit polyclonal SET antibody (1:1,000 dilution; catalog no. sc-25564), rabbit polyclonal Bcl-2 antibody (1:500 dilution; catalog no. sc-492), rabbit polyclonal Bax antibody (1:1,000 dilution; catalog no. sc-623), mouse monoclonal caspase- 3 antibody (1:800 dilution; catalog no. sc-65497) and mouse monoclonal $\beta$-actin antibody (1:1,000 dilution; catalog no. sc-8432). The secondary antiobodies used were anti-rabbit immunoglobulin (Ig)G (catalog no. zb2301) and anti-mouse IgG (catalog no. zb2305) horseradish peroxidase-conjugated antibodies (1:2,000 dilution; Santa Cruz Biotechnology, Inc., Dallas, TX, USA). Detection was performed using a Chemiluminescent Western Blot detection kit (Thermo Fisher Scientific, Inc., Waltham, MA, USA).

$I H C$. Glioblastoma tissue specimens were fixed in formalin and embedded in paraffin. The sections were cut to $4 \mu \mathrm{m}$. After dewaxing with xylene and rehydrating with sequential ethanol, the sections were blocked with $3 \% \mathrm{H}_{2} \mathrm{O}_{2}$ at room
Table I. Clinicopathological parameters of 26 patients with glioblastoma.

\begin{tabular}{ll} 
Parameter & $\mathrm{n}$ \\
\hline Gender & \\
Female & 12 \\
Male & 14 \\
Age, years & \\
$\geq 50$ & 14 \\
$<50$ & 12 \\
WHO classification & \\
I & \\
II & 3 \\
III & 6 \\
IV & 6
\end{tabular}

Differentiation degree ${ }^{b}$

Well

Moderate 6

Low

${ }^{\mathrm{a}}$ According to the $2007 \mathrm{WHO}$ classification (17). ${ }^{\mathrm{b}}$ According to glioma grading (18). WHO, World Health Organization.

temperature for endogenous peroxidase ablation for $10 \mathrm{~min}$, and antigen retrieval was performed with citrate buffer at $\sim 95^{\circ} \mathrm{C}$ for $20 \mathrm{~min}$. After rinsing in phosphate-buffered saline (PBS) with Tween 20 (0.01 M of PBS, pH 7.4; 3x5 min), the sections were incubated with goat serum (Zhongshan Goldenbridge Biotechnology Co., Ltd., Beijing, China) at $37^{\circ} \mathrm{C}$ for $30 \mathrm{~min}$. Subsequently, samples were incubated with rabbit SET antibody (Santa Cruz Biotechnology, Inc.) diluted in PBS (0.01 M of PBS, pH 7.4) at $4^{\circ} \mathrm{C}$ overnight followed by biotin-labeled goat anti-rabbit $\mathrm{IgG}$ and streptavidin/horseradish-peroxidase at $37^{\circ} \mathrm{C}$ for $1 \mathrm{~h}$. Then, the sections were stained with 3,3'-diaminobenzidine (Zhongshan Goldenbridge Biotechnology Co., Ltd.) in the dark for $\sim 2 \mathrm{~min}$ until coloration (Nikon TS100; Nikon Corporation, Tokyo, Japan) was complete, counterstained with hematoxylin for 2 min, dehydrated, cleared with running water and mounted with neutral gums. The same steps were conducted for the negative control group, but the rabbit SET antibody was replaced with PBS.

Staining intensity was graded as 0 (negative), 1 (weak), 2 (moderate) or 3 (strong); while staining extent was graded as $0(<5 \%), 1(5-25 \%), 2(25-50 \%), 3(50-75 \%)$ or $4(>75 \%)$. The sum of the staining intensity and extent values were used to determine the final expression of SET, as follows: 0 (negative, + ), 2-3 (weak positive, + ), 4-5 (moderate positive, ++ ) and 6-7 (strong positive, +++ ). Optical density (OD) values of SET expression were examined with Image ProPlus 6.0 software (Media Cybernetics, Inc., Rockville, MD, USA).

Cell lines and culture conditions. Human glioblastoma cell lines, U87MG and U251 (American Type Culture Collection, Manassas, VA, USA), were cultured in Dulbecco's Modified Eagle's medium (DMEM; Hyclone; GE Healthcare Life 
Table II. Primer sequences for reverse transcription-quantitative polymerase chain reaction.

\begin{tabular}{|c|c|c|c|}
\hline Gene & Primer sequence & Location & Product length, bp \\
\hline SET & $\begin{array}{l}\text { 5'-GCTCAACTCCAACCACGAC-3' } \\
\text { 5'-TCCTCACTGGCTTGTTCATTA-3' }\end{array}$ & $\begin{array}{l}389-407 \\
508-488\end{array}$ & 120 \\
\hline Bax & $\begin{array}{l}\text { 5'-AAGCTGAGCGAGTGTCTCAAG-3' } \\
\text { 5'-CAAAGTAGAAAAGGGCGACAAC-3' }\end{array}$ & $\begin{array}{l}172-192 \\
349-328\end{array}$ & 178 \\
\hline$B c l-2$ & $\begin{array}{l}\text { 5'-GTTTGATTTCTCCTGGCTGTCTC-3' } \\
\text { 5'-GAACCTTTTGCATATTTGTTTGG-3' }\end{array}$ & $\begin{array}{c}1-23 \\
649-627\end{array}$ & 133 \\
\hline Caspase-3 & $\begin{array}{l}\text { 5'-ATCACAGCAAAAGGAGCAGTTT-3' } \\
\text { 5'-ACACCACTGTCTGTCTCAATGC-3' }\end{array}$ & $\begin{array}{l}583-604 \\
796-775\end{array}$ & 214 \\
\hline GAPDH & $\begin{array}{l}\text { 5'-GGAAGGTGAAGGTCGGAGT-3' } \\
\text { 5'-TGAGGTCAATGAAGGGGTC-3' }\end{array}$ & $\begin{array}{l}107-125 \\
223-205\end{array}$ & 117 \\
\hline
\end{tabular}

Sciences, Logan, UT, USA) containing $10 \%$ fetal bovine serum, penicillin (100 IU/ml) and streptomycin $(100 \mu \mathrm{g} / \mathrm{ml})$. Cells were grown at $37^{\circ} \mathrm{C}$ in a humidified atmosphere with $5 \% \mathrm{CO}_{2}$. Experiments were performed using cells harvested from exponentially growing cultures.

RNA interference (RNAi) of SET. Three groups were established as follows: Non-treatment control (blank), negative control (NC; control siRNA) and experimental groups. siRNA experiments were performed using $5 \mu$ l Lipofectamine 2000 (Invitrogen; Thermo Fisher Scientific, Inc.) to transfect 50 nM siRNA (siRNA sequences, 5'-GGAGGAAGGAUU AGAAGAUdTdT-3'; and 3'-dTdTGACCUUUCCUAAAC UGCUU-5') when cell density reached $3 \times 10^{5}$ cells/well in a 6-well plate (Corning Life Sciences, Tewksbury, MA, USA). Negative experiments were performed using $5 \mu \mathrm{l}$ Lipofectamine 2000 to transfect $50 \mathrm{Nm}$ negative control RNA when the cell density reached $3 \times 10^{5}$ cells/well in a 6 -well plate, while in the blank group, only culture medium without serum and antibiotics was used when the cell density reached $3 \times 10^{5}$ cells/well in a 6 -well plate. The transfection medium was removed after $6 \mathrm{~h}$ and replaced with fresh growth medium. Transfected cells were collected at $48 \mathrm{~h}$ to detect mRNA expression levels by RT-qPCR and at $72 \mathrm{~h}$ to detect protein expression levels by western blotting.

Cell proliferation assay. Cells in the logarithmic phase were cultured in 96-well culture plates at a cell density of $10^{3}$ cells/well in medium with $10 \%$ fetal bovine serum (FBS; Gibco; Thermo Fisher Scientific, Inc.). CCK-8 reagents (10 $\mu \mathrm{l}$; Sigma-Aldrich, St. Louis, MO, USA) were added at various time points $(12,24,36,48$ and $60 \mathrm{~h})$. After cells were cultured for $2 \mathrm{~h}$, the medium was removed, $150 \mu \mathrm{l}$ dimethylsulfoxide was added into each well and cells were incubated for $15 \mathrm{~min}$. Plates were read at an absorbance wavelength of $450 \mathrm{~nm}$ using a microplate reader (Model 680; Bio-Rad Laboratories, Hercules, CA USA). Each transfection group had six replicates and the experiment was repeated three times.

Flow cytometry. Cells in the logarithmic phase were collected and cultured in 6-well culture plates. In the cell apoptosis experiment, cells were collected at $24 \mathrm{~h}$ post-transfection,
Table III. Polymerase chain reaction cycling conditions

\begin{tabular}{ll}
\hline Gene & Conditions \\
\hline Set & $95^{\circ} \mathrm{C} 30 \mathrm{sec} ; 95^{\circ} \mathrm{C} 10 \mathrm{sec} ; 62^{\circ} \mathrm{C} 30 \mathrm{sec} ;$ \\
& $68^{\circ} \mathrm{C} 20 \mathrm{sec}$ for $40 \mathrm{cycles} ;$ \\
Bax & $95^{\circ} \mathrm{C} 30 \mathrm{sec} ; 95^{\circ} \mathrm{C} 10 \mathrm{sec} ; 60^{\circ} \mathrm{C} 30 \mathrm{sec} ;$ \\
& $68^{\circ} \mathrm{C} 20 \mathrm{sec} ;$ for $40 \mathrm{cycles} ;$ \\
Bcl-2 & $95^{\circ} \mathrm{C} 30 \mathrm{sec} ; 95^{\circ} \mathrm{C} 10 \mathrm{sec} ; 57^{\circ} \mathrm{C} 30 \mathrm{sec} ;$ \\
& $68^{\circ} \mathrm{C} 20 \mathrm{sec} ;$ for $40 \mathrm{cycles} ;$ \\
Caspase-3 & $95^{\circ} \mathrm{C} 30 \mathrm{sec} ; 95^{\circ} \mathrm{C} 10 \mathrm{sec} ; 60^{\circ} \mathrm{C} 30 \mathrm{sec} ;$ \\
& $68^{\circ} \mathrm{C} 20 \mathrm{sec} ;$ for $40 \mathrm{cycles}$ \\
GAPDH & $95^{\circ} \mathrm{C} 30 \mathrm{sec} ; 95^{\circ} \mathrm{C} 10 \mathrm{sec} ; 58^{\circ} \mathrm{C} 30 \mathrm{sec} ;$ \\
& $68^{\circ} \mathrm{C} 20 \mathrm{sec} ;$ for $40 \mathrm{cycles} ;$ \\
\hline
\end{tabular}

washed twice using PBS and centrifuged at $370 \mathrm{x} g$ (5 min at $\left.4^{\circ} \mathrm{C}\right)$. Cell pellets were suspended in $400 \mu \mathrm{l} \mathrm{PBS}$, then $5 \mu \mathrm{l}$ Annexin V-fluorescein isothiocyanate (BD Biosciences, Franklin Lakes, NJ, USA) was added. The mixture was gently agitated and placed in room temperature for $10 \mathrm{~min}$. Subsequently, $10 \mu \mathrm{l}$ propidium iodide $(20 \mu \mathrm{g} / \mathrm{ml}$; BD Biosciences) was added and incubated for $30 \mathrm{~min}$ at $4^{\circ} \mathrm{C}$. The effect of SET siRNA on cell apoptosis was analyzed by flow cytometry (FACSAria II Cell Sorter; BD Biosciences). Each transfection group had three replicates and the experiment was repeated three times.

Cell migration assay. A Transwell migration assay was performed to examine cell proliferation. Cells in the logarithmic phase were cultured and seeded into the upper chamber of a Transwell (EMD Millipore, Billerica, MA, USA) at a density of $2 \times 10^{5}$ cells/well in medium without FBS. Medium containing $10 \%$ FBS was placed in the lower chamber to act as a chemoattractant. After $48 \mathrm{~h}$, non-migratory cells that remained on the upper chambers were removed by scraping them with a cotton swab. Cells that migrated to the lower surface through the $8.0-\mu \mathrm{m}$ polycarbonate membrane were stained with $0.1 \%$ crystal violet for $15 \mathrm{~min}$. Migrated cells were quantified by counting stained cells under a microscope (x400 magnification). Five random fields were selected for each well to determine the total number of migrated cells. 


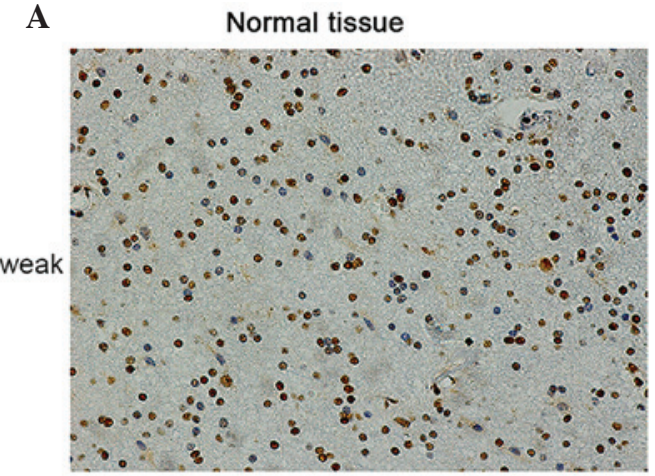

B
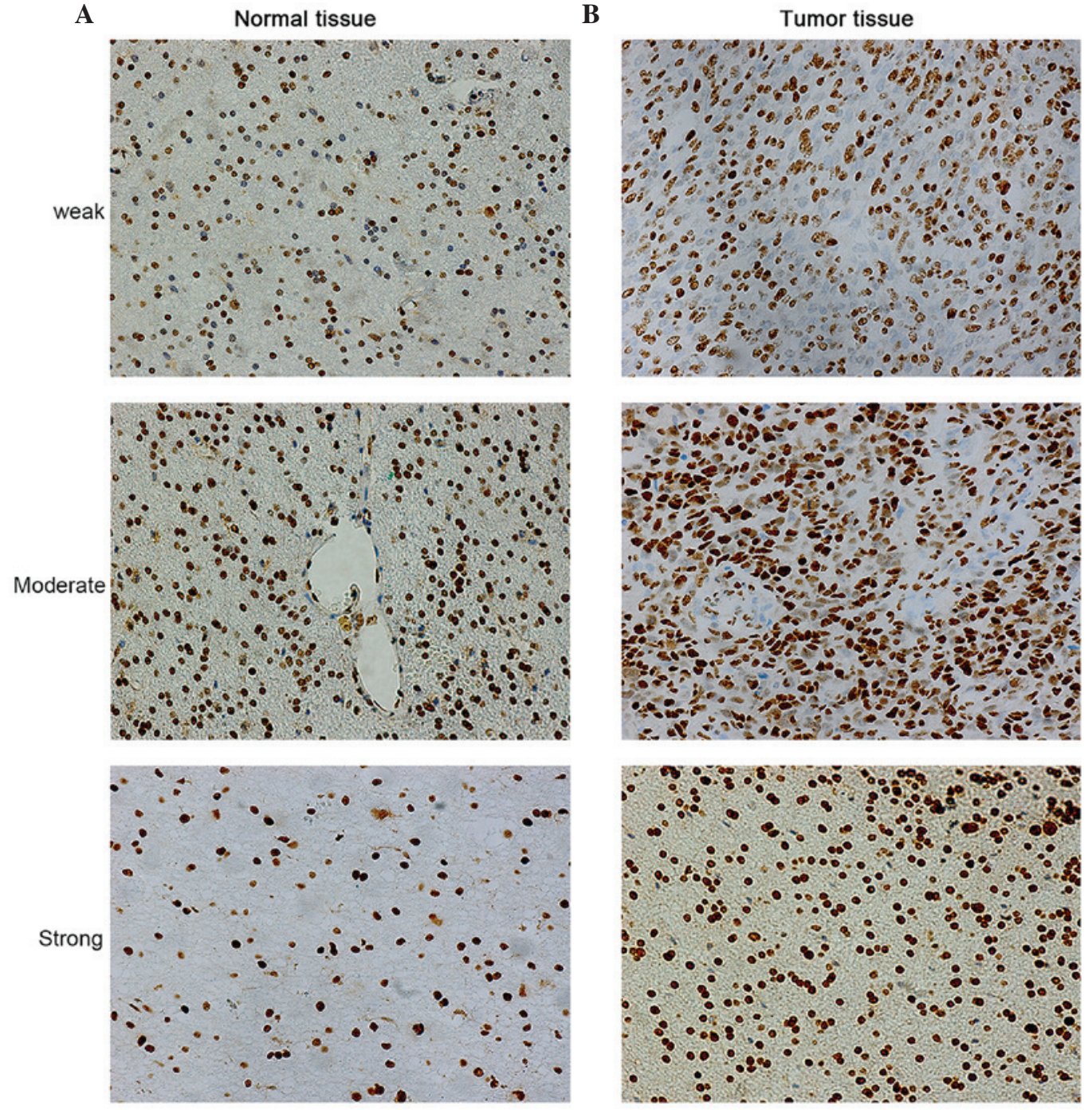

Figure 1. Representative immunohistochemical expression patterns of SET in (A) normal brain and (B) glioblastoma tumor specimens (stain, 3,3'-Diaminobenzidine and hematoxylin; magnification, x400).

The assay was performed in triplicate and repeated three times.

RT-qPCR analysis. RT-qPCR was used to detect differences in mRNA expression. After transfection for 24-36 h, RNA was extracted from cells using TRIzol reagent (Invitrogen; Thermo Fisher Scientific, Inc.), according to manufacturer's instructions. The RNA was purified using a total of $10 \mu \mathrm{l}$ reagent, including $2 \mu \mathrm{l} 5 \mathrm{X}$ gDNA Eraser Buffer, $1 \mu \mathrm{l}$ gDNA Eraser, $1 \mu \mathrm{g}$ RNA and RNase-Free $\mathrm{dH}_{2} \mathrm{O}$ (amount determined by the concentration of RNA) at $42^{\circ} \mathrm{C}$ for $2 \mathrm{~min}$. Total RNA $(1 \mu \mathrm{g})$ was reverse transcribed using an M-Mulv reverse transcriptase kit (Takara, Japan). qPCR was then performed with $2 \mu \mathrm{l}$ cDNA using SYBR Premix Ex Taq (Takara, Japan), according to manufacturer's instructions and in accordance with international standards (6-8). Primers are indicated in Table II and the amplification was performed on a Bio-Rad C1000 Touch Thermal Cycler (Bio-Rad Laboratories). PCR cycling conditions are stated in Table III. The GAPDH gene was used as an endogenous control and the $\triangle \Delta \mathrm{Cq}$ method was used to quantify the data (19) and the experiment was repeated three times.
Western blot analysis. Cells were lysed in ice-cold RIPA buffer (Beyotime Institute of Biotechnology, Nantong, China). Total protein concentration was determined using an Enhanced BCA Protein assay kit (Beyotime Institute of Biotechnology). Equal amounts of proteins were separated by $12 \%$ SDS-PAGE and transferred onto PVDF membranes (EMD Millipore). After blocking in Tris-buffered saline containing 5\% non-fat milk, the membranes were incubated with primary antibodies at $4{ }^{\circ} \mathrm{C}$ overnight; followed by incubation with horseradish peroxidase-conjugated anti-rabbit antibody (Santa Cruz Biotechnologies, Inc.) at room temperature for $1 \mathrm{~h}$. Signals were detected on a gel imaging system using the electrochemiluminescent western blotting substrate (Thermo Fisher Scientific, Inc.). The expression of $\beta$-actin was used as the loading control. Quantity One software (v.4.62; Bio-Rad Laboratories) was used for quantification.

Statistical analysis. Data are presented in means \pm standard deviation of at least three separate experiments. Independent-samples t-test and paired-samples t-test were used for comparison of normally distributed data. SPSS statistical software package (version 18; SPSS, Inc., Chicago, IL, USA) 
Table IV. OD values for SET expression in association with clinicopathological parameters of cancer samples.

\begin{tabular}{lcc}
\hline Parameter & OD $($ mean \pm SD $)$ & P-value \\
\hline Gender & & \\
Female & $0.89 \pm 0.19$ & 0.002 \\
Male & $1.0 \pm 0.16$ & \\
Age, years & & \\
$\geq 50$ & $0.99 \pm 0.17$ & 0.419 \\
$<50$ & $0.90 \pm 0.18$ & \\
WHO classification & \\
I & & \\
II & $0.58 \pm 0.14$ & 0.304 \\
III & $0.90 \pm 0.11$ & 0.031 \\
IV & $0.91 \pm 0.20$ & 0.003 \\
Differentiation degree & $1.11 \pm 0.12$ & 0.001 \\
Well & & \\
Moderate & $0.58 \pm 0.14$ & 0.298 \\
Low & $0.90 \pm 0.11$ & 0.031 \\
\hline
\end{tabular}

according to the 2007 WHO classification (17). ${ }^{\mathrm{b}}$ According to glioma grading (18). OD values (mean \pm SD) for the total normal and cancer samples were $0.54 \pm 0.14$ and $0.91 \pm 0.20$, respectively. OD, optical density; SD, standard deviation; WHO, World Health Organization

was used for statistical analysis. $\mathrm{P}<0.05$ was considered to indicate a statistically significant difference.

\section{Results}

Expression of SET in glioma tissues. Representative staining of SET in glioma tissues is shown in Fig. 1. Positive expression of SET was observed in the cell nucleus. SET protein expression was detected in $100 \%$ (20/20) of cancer samples. Among the 18 cases of glioma and 2 cases of meningioma, $15 \%(3 / 20)$, $25 \%(5 / 20)$ and $60 \%(12 / 20)$ of cases exhibited weak $(+)$, moderate $(++)$ and strong $(+++)$ SET protein staining, respectively. By contrast, among the 12 normal tissues, including 6 adjacent normal tissue and 6 other patient samples, $83.33 \%$ $(10 / 12), 8.33 \%(1 / 12)$ and $8.33 \%(1 / 12)$ of normal brain specimens exhibited weak (+), moderate (++) and strong (+++) SET protein staining, respectively. The OD of SET was examined by Image ProPlus software. Results revealed that the protein expression level of SET significantly increased in glioma tissues compared with normal brain specimens $(\mathrm{P}=0.001)$. Thus, SET appears to be frequently upregulated in glioma tissues at the protein level. In addition, there were significant associations between SET expression and gender $(\mathrm{P}=0.002)$, World Health Organization grade II (18) $(\mathrm{P}=0.031)$, III $(\mathrm{P}=0.003)$ and IV $(\mathrm{P}=0.001)$ cancer, and moderately-differentiated $(\mathrm{P}=0.031)$ and poorly-differentiated $(\mathrm{P}=0.001)$ cancer. However, the association between SET expression and age $(\mathrm{P}=0.419)$, WHO grade I cancer $(\mathrm{P}=0.304)$ and well-differentiated cancer $(\mathrm{P}=0.298)$ were not statistically significant (Table IV).
Inhibition of SET promotes cell apoptosis. Following transfection for $48 \mathrm{~h}$, the cell apoptosis rates of $\mathrm{U} 87 \mathrm{MG}^{-\mathrm{SET}}, \mathrm{U} 87 \mathrm{MG}^{-\mathrm{NC}}$ and $\mathrm{U} 87 \mathrm{MG}$ cells were $71.8 \pm 2.92,44.17 \pm 1.48$ and $38.56 \pm 4.61 \%$, respectively. The cell apoptosis rate of $\mathrm{U} 87 \mathrm{MG}^{\text {-SET }}$ cells was significantly higher than that of $\mathrm{U}^{2} 7 \mathrm{MG}^{-\mathrm{NC}}(\mathrm{P}=0.001)$ and U87MG $(\mathrm{P}=0.001)$ cells. There was no statistical significance noted between $\mathrm{U} 87 \mathrm{MG}^{-\mathrm{NC}}$ and U87MG cells $(\mathrm{P}=0.161)$. The apoptosis rates of $\mathrm{U} 251^{-\mathrm{SET}}, \mathrm{U} 251^{-\mathrm{NC}}$ and $\mathrm{U} 251$ cells were $86.2 \pm 1.54,59.33 \pm 0.93$ and $59.3 \pm 0.46 \%$, respectively. The $\mathrm{U} 251^{\text {-SET }}$ cell apoptosis rate was significantly higher than that of $\mathrm{U} 251^{-\mathrm{NC}}(\mathrm{P}<0.01)$ and $\mathrm{U} 251(\mathrm{P}<0.01)$ cells. No statistically significant difference was found between the $\mathrm{U} 251^{-\mathrm{NC}}$ and U251 cells ( $\mathrm{P}=0.479)$ (Fig. 2).

Inhibition of SET downregulates cell proliferation. Compared with the blank group, cell proliferation significantly declined

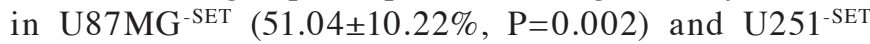
$(32.45 \pm 6.99 \%, \mathrm{P}=0.015)$ cells, respectively, in a time-dependent manner (12, 24, 36, 48 and $60 \mathrm{~h}$ after transfection). However, there was no statistically significant difference in

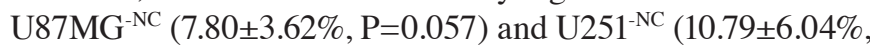
$\mathrm{P}=0.110$ ) cells (Fig. 3 ).

Inhibition of SET reduces cell migration. Following transfection for $24 \mathrm{~h}$, the number of $\mathrm{U}^{8} 7 \mathrm{MG}^{-\mathrm{SET}}, \mathrm{U} 87 \mathrm{MG}^{-\mathrm{NC}}$ and U87MG cells that migrated was $114 \pm 6,170 \pm 8$ and $177 \pm 9$, respectively. Furthermore, the number of migrated U251-SET, $\mathrm{U} 251^{-\mathrm{NC}}$ and $\mathrm{U} 251$ cells was $79 \pm 2,153 \pm 5$ and $162 \pm 7$, respectively, compared with the blank group; and the number of cells in the experimental group was significantly inhibited in

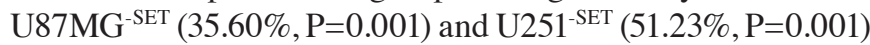
cells. There was no statistically significant difference between

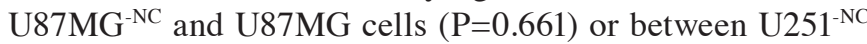
and $\mathrm{U} 251$ cells $(\mathrm{P}=0.146)$ (Fig. 4).

Bcl-2, Bax and caspase-3 mRNA expression levels in $U 87 M G^{-S E T}$ and $U 251^{-S E T}$ cells. Following transfection for $48 \mathrm{~h}$, SET gene expression was inhibited in $\mathrm{U} 7 \mathrm{MG}^{-\mathrm{SET}}(75.7 \pm 4.9 \%$, $\mathrm{P}=0.006)$ and $\mathrm{U} 251^{\text {-SET }}(79.92 \pm 8.77 \%, \mathrm{P}<0.01)$ cells compared with the blank groups, and in $\mathrm{U} 87 \mathrm{MG}^{-\mathrm{NC}}$ cells $(7.72 \pm 4.65 \%$, $\mathrm{P}=0.053)$ and $\mathrm{U} 251^{-\mathrm{NC}}$ cells $(8.61 \pm 5.1 \%, \mathrm{P}=0.100)$. Similarly, the Bcl-2 mRNA expression level was decreased in $\mathrm{U} 7 \mathrm{MG}^{\text {-SET }}$ $(63.31 \pm 10.81 \%, \mathrm{P}=0.020)$ and $\mathrm{U} 251^{\text {-SET }}(68.25 \pm 17.17 \%$, $\mathrm{P}=0.001)$ cells. No statistically significant difference was

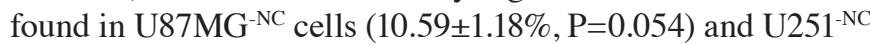
cells $(7.36 \pm 5.83 \%, \mathrm{P}=0.160)$ cells compared with the blank groups. In contrast to Bcl-2, the mRNA expression levels of

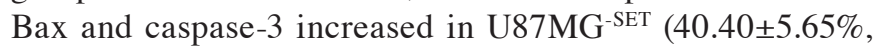
$\mathrm{P}=0.014$ and $36.30 \pm 8.63 \%, \mathrm{P}=0.023$, respectively), and $\mathrm{U} 251^{\text {-SET }}(41.58 \pm 17.13 \%, \mathrm{P}=0.005$ and $79.54 \pm 11.15 \%, \mathrm{P}=0.014$, respectively); however, in the $\mathrm{U} 87 \mathrm{MG}^{-\mathrm{NC}}$ cells $(0.36 \pm 10.79 \%$, $\mathrm{P}=0.628 ; 10.85 \pm 6.60 \%, \mathrm{P}=0.059)$ and the $\mathrm{U} 251^{-\mathrm{NC}}$ cells $(10.30 \pm 6.60 \%, \mathrm{P}=0.064 ; 9.69 \pm 6.40 \%, \mathrm{P}=0.120)$, there was no statistical compared with the blank group. (Fig. 5).

Bcl-2, Bax and caspase-3 protein expression levels in $U 87 M G^{-S E T}$ and $U 251^{-S E T}$ cells. Following transfection for

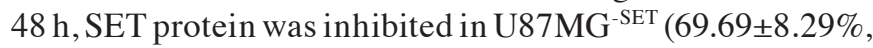
$\mathrm{P}=0.005)$ and $\mathrm{U} 251^{\text {-SET }}(70.52 \pm 5.67 \%, \mathrm{P}<0.001)$ cells, while the inhibition rate was $9.12 \pm 3.19 \%(\mathrm{P}=0.054)$ and 
A
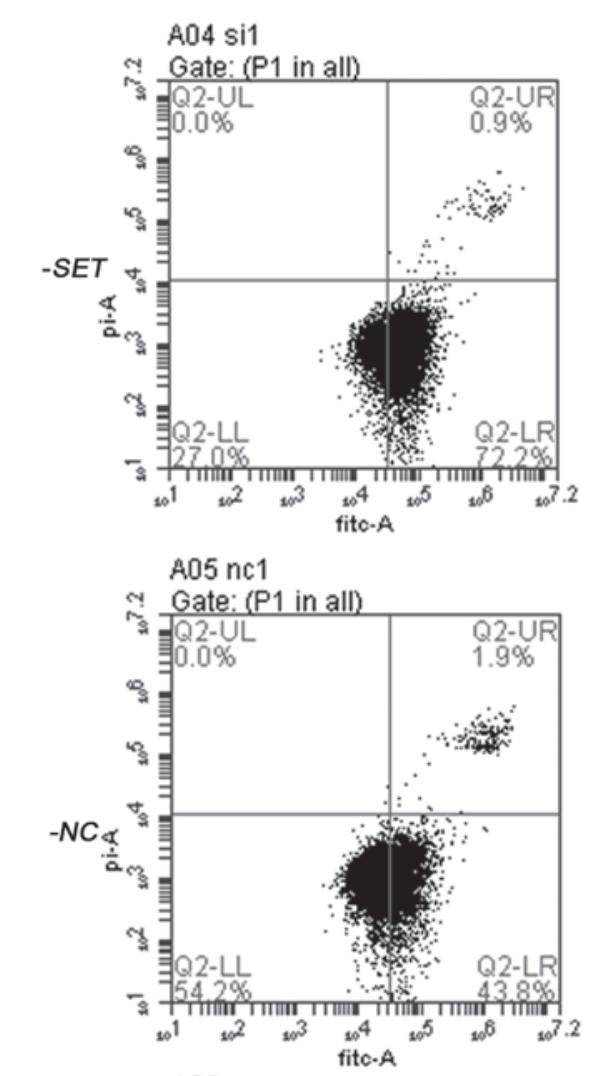

$\mathrm{A} 06 \mathrm{zC}$

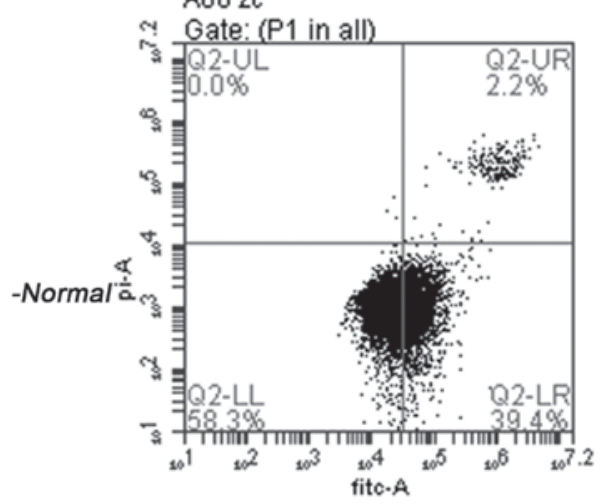

C

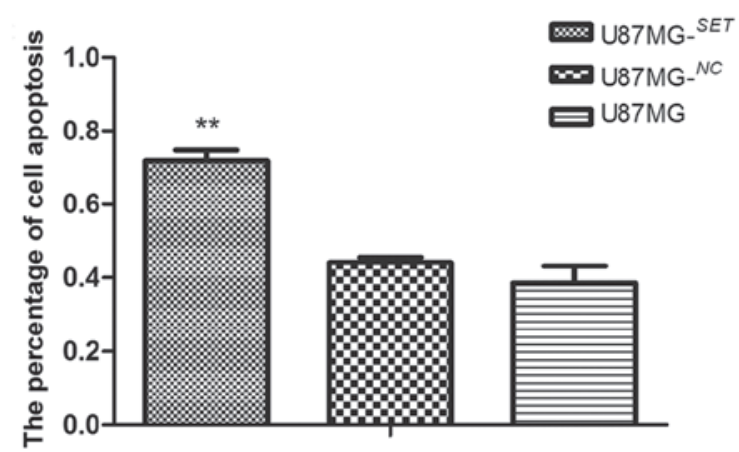

B

U251

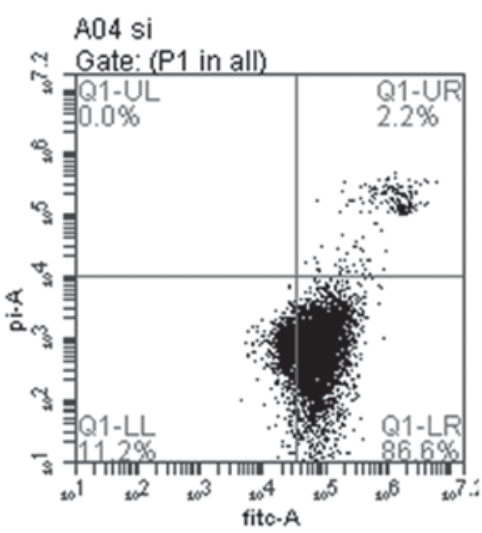

$\mathrm{A} 05 \mathrm{nc}$

T. Gate: (P1 in all)

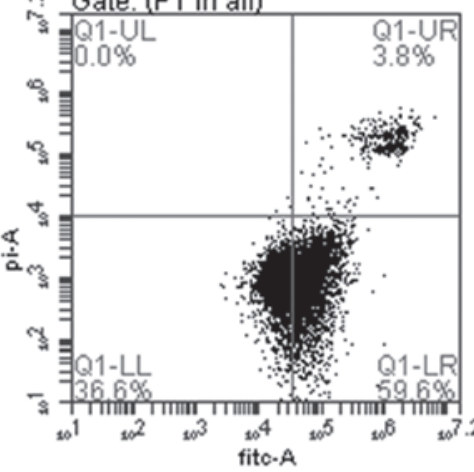

$\mathrm{A} 06 \mathrm{zc}$

Gate: (P1 in all)

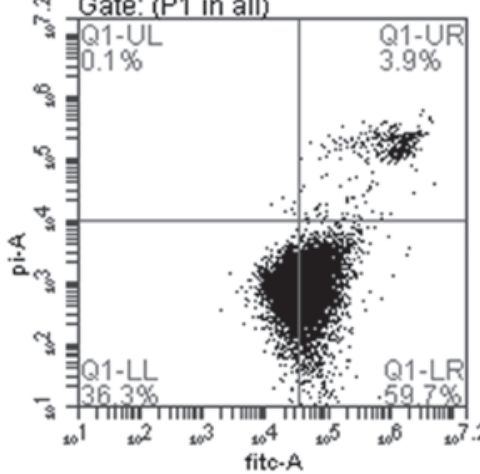

D

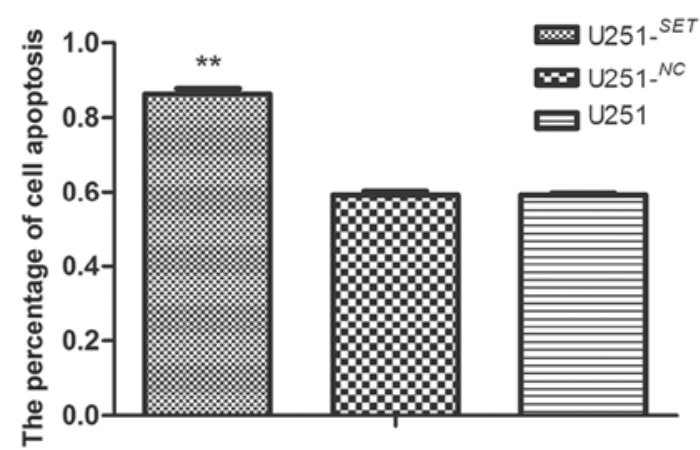

Figure 2. Effect of SET on cell apoptosis. Apoptosis rates of (A) U87MG ${ }^{\text {-SET }}$, U87MG ${ }^{-\mathrm{NC}}$ and U87MG cells, and (B) U251-SET , U251 ${ }^{-\mathrm{NC}}$ and U8251 cells, as determined by flow cytometry. Compared with the NC and blank groups, significant inhibition of SET resulted in significantly upregulated cell apoptosis in (C) $\mathrm{U}_{87 \mathrm{MG}^{-\mathrm{SET}}}(\mathrm{P}=0.001)$ and $(\mathrm{D}) \mathrm{U} 251^{-\mathrm{SET}}(\mathrm{P}<0.01)$ cells. Data are presented as the mean \pm standard deviation. ${ }^{* *} \mathrm{P}<0.01$ vs. NC and blank control groups. PI; propidium iodide; FITC, fluorescein isothiocyanate; NC, negative control.

$9.51 \pm 5.31 \%(\mathrm{P}=0.098)$ in the $\mathrm{U} 87 \mathrm{MG}^{-\mathrm{NC}}$ and $\mathrm{U} 251^{-\mathrm{NC}}$ cells, respectively, compared with the blank group. The protein expression level of $\mathrm{Bcl}-2$ was also inhibited in $\mathrm{U}^{8} \mathrm{MG}^{-\mathrm{SET}}$
$(66.03 \pm 11.33 \%, \mathrm{P}=0.008)$ and $\mathrm{U} 251^{-\mathrm{SET}}(61.09 \pm 6.41 \%$, $\mathrm{P}=0.001)$ cells, and in the $\mathrm{U} 87 \mathrm{MG}^{-\mathrm{NC}}(10.32 \pm 10.04, \mathrm{P}=0.087)$ and the $\mathrm{U} 251^{-\mathrm{NC}}(10.47 \pm 5.73, \mathrm{P}=0.217)$ cells; while $\mathrm{Bax}$ and 

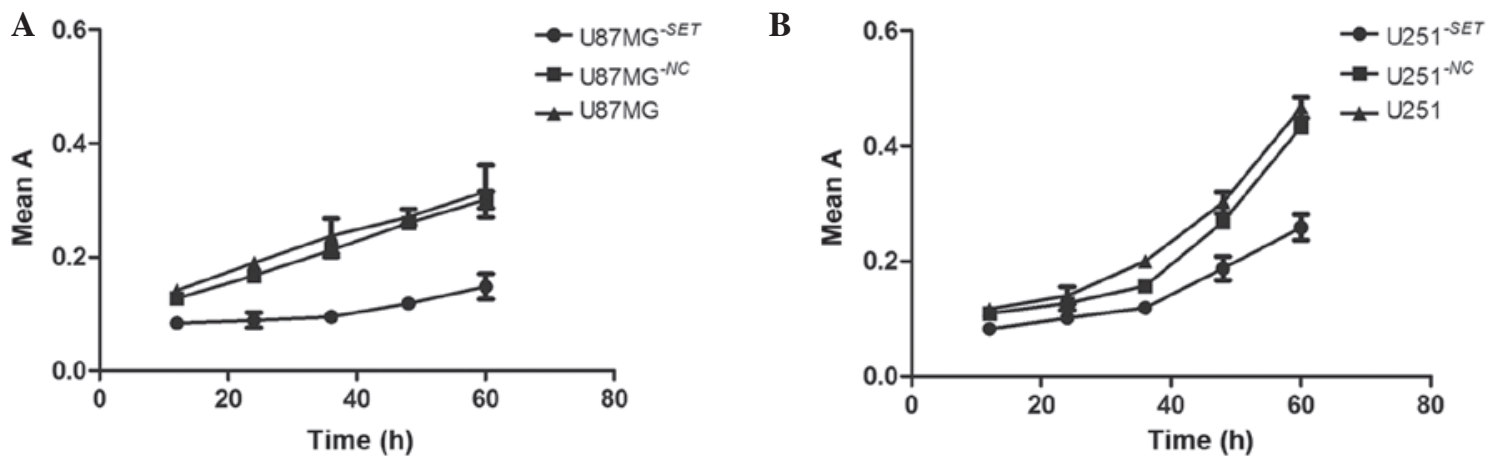

Figure 3. Effect of SET on cell proliferation. Inhibition of SET decreases (A) U87MG-SET $(\mathrm{P}=0.002)$ and $(\mathrm{B}) \mathrm{U} 251^{-\mathrm{SET}}(\mathrm{P}=0.015)$ cell proliferation compared with the $\mathrm{NC}$ and blank control groups. Data are presented as the mean \pm standard deviation. A, absorbance; NC, negative control.

A

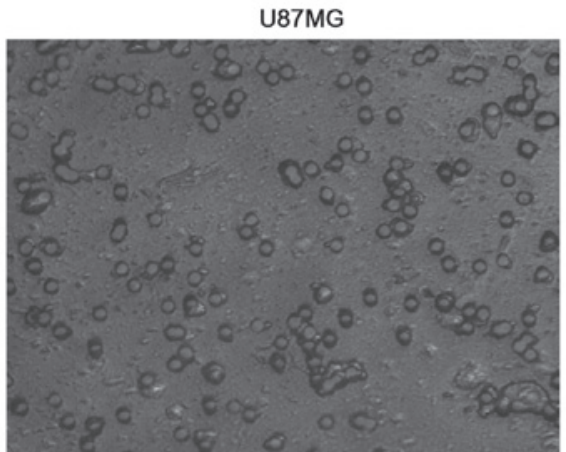

NC

-NORMAL
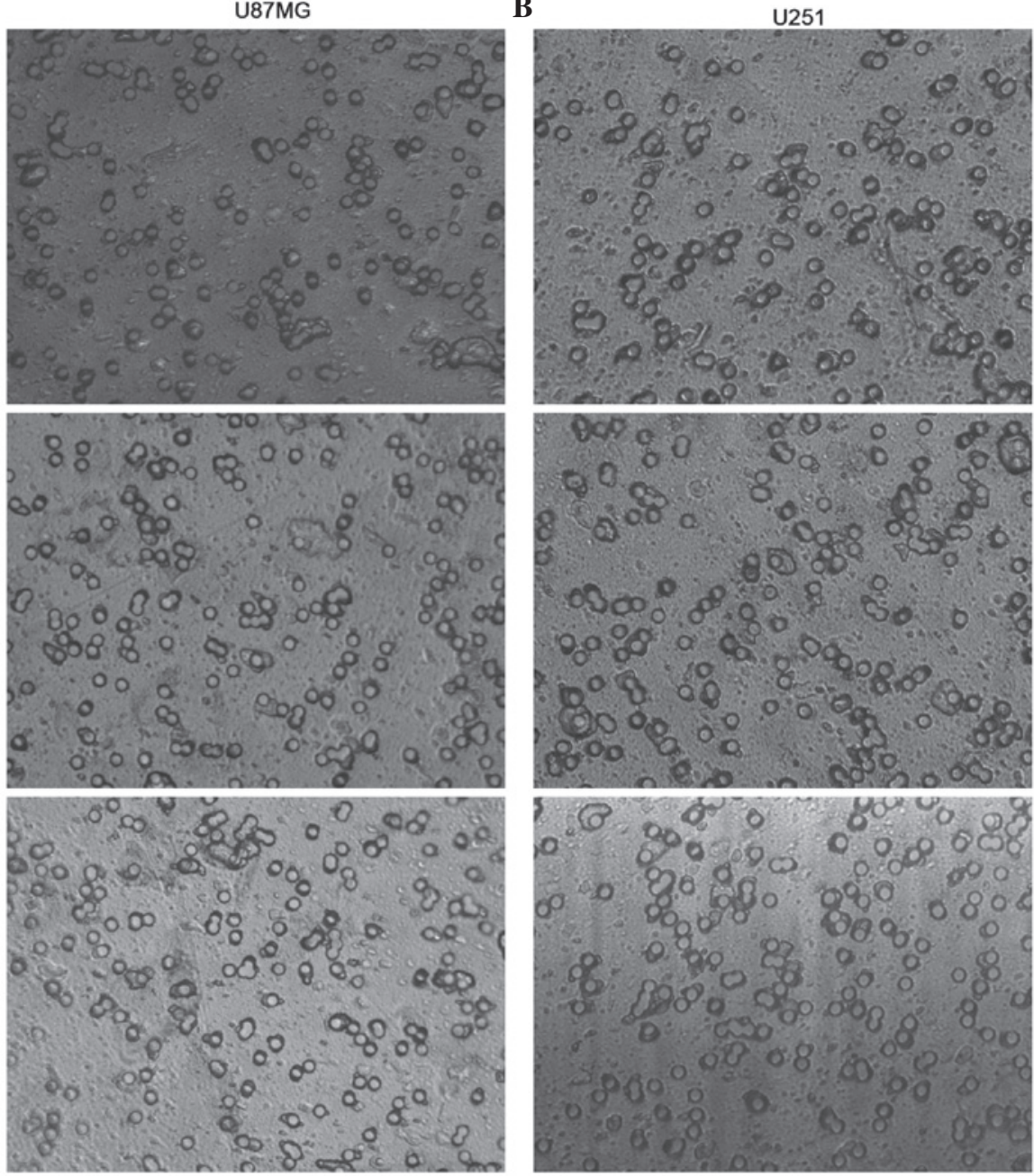

C

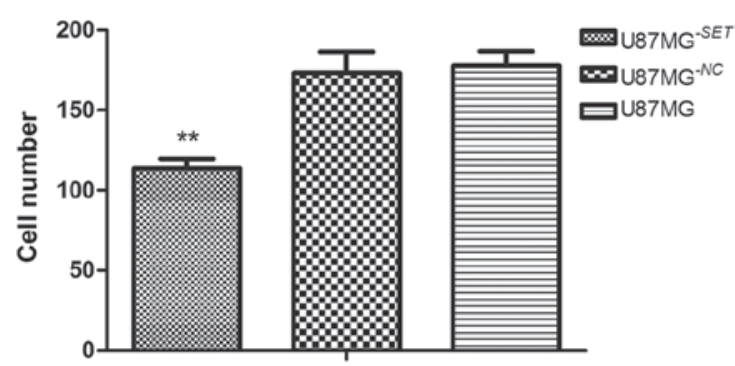

D

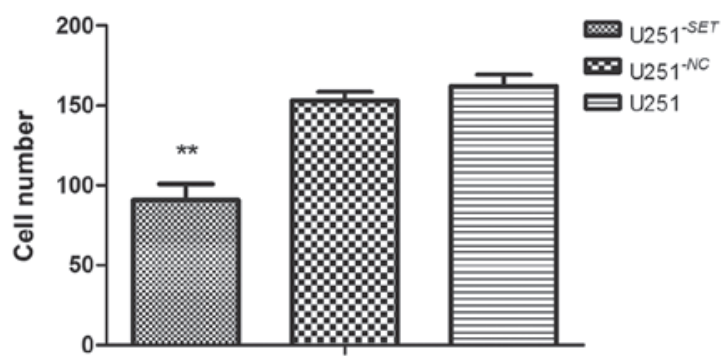

Figure 4. Effect of SET on cell migration. Cell migration in (A) U87MG ${ }^{-\mathrm{SET}}$, U87MG ${ }^{-\mathrm{NC}}$ and U87MG cells, and in (B) $251^{\text {-SET }}$, U251 ${ }^{-\mathrm{NC}}$ and U8251 cells (magnification, $\mathrm{x} 400$ ). Compared with the NC and blank groups, after SET was significantly inhibited, cell migration was significantly downregulated in (C) $\mathrm{U}_{87 \mathrm{MG}^{-\mathrm{SET}}}(\mathrm{P}=0.001)$ and $(\mathrm{D}) \mathrm{U} 251^{\mathrm{SET}}(\mathrm{P}=0.001)$ cells. Data are presented as the mean \pm standard deviation. ${ }^{* *} \mathrm{P}<0.01$ vs. NC and blank control groups. $\mathrm{NC}$, negative control. 
A

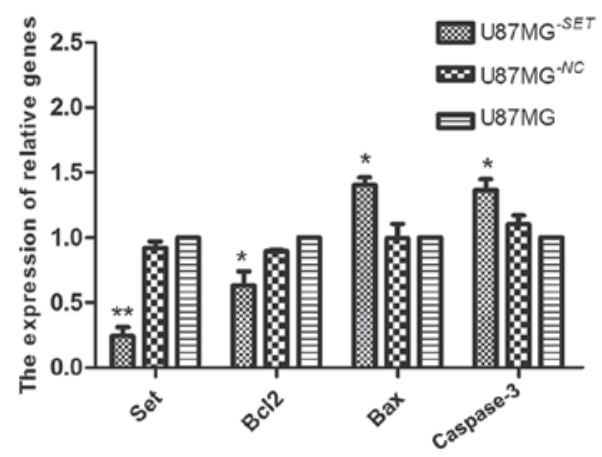

B

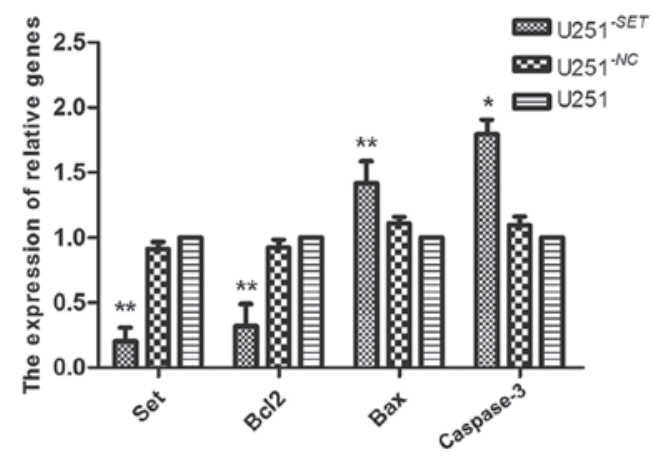

Figure 5. Downregulation of SET can significantly change the mRNA expression of Bcl-2, Bax and caspase-3. Compared with the NC and blank groups, the mRNA expression levels of Bax and caspase-3 were significantly upregulated while the mRNA expression level of Bcl-2 was significantly downregulated in

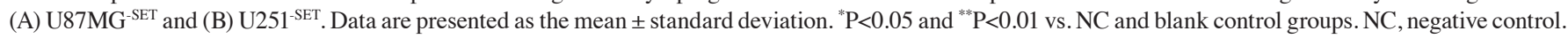
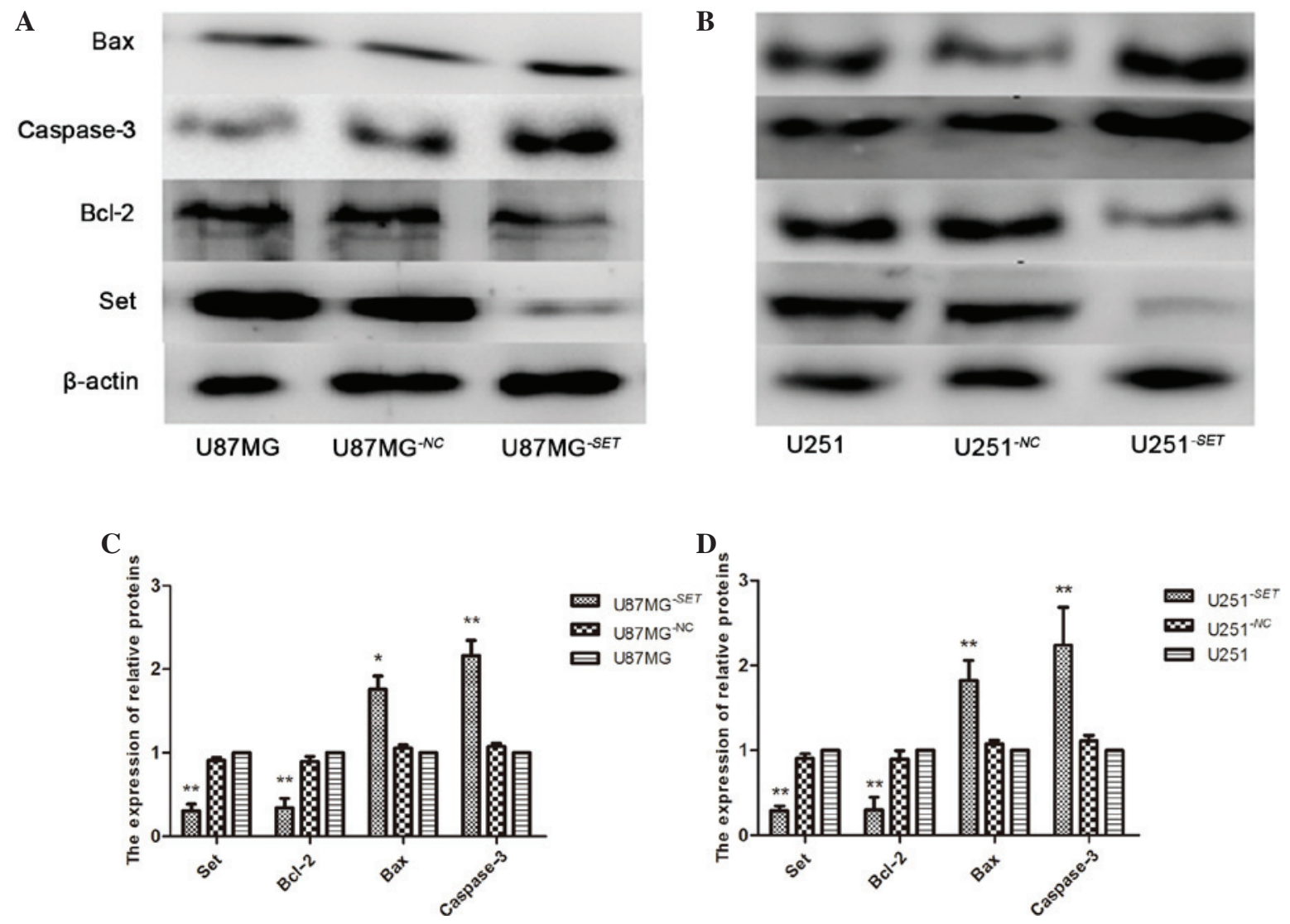

Figure 6. Downregulation of SET can significantly change the protein expression of Bcl-2, Bax and caspase-3. Western blots of (A) U87MG and (B) U251 cell lines were $(\mathrm{C}$ and $\mathrm{D})$ quantified. The data revealed that, after SET was significantly inhibited, the protein expression level of Bcl-2 decreased, while the expression of Bax and caspase- 3 increased compared with the NC and blank groups. Data are presented as the mean \pm standard deviation. ${ }^{*} \mathrm{P}<0.05$, ${ }^{* * *} \mathrm{P}<0.01$ vs. NC and blank control groups. NC, negative control.

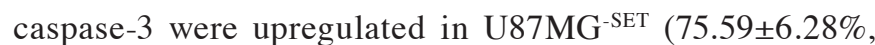
$\mathrm{P}=0.015$ and $115.76 \pm 15.18 \%, \mathrm{P}<0.001$, respectively) and $\mathrm{U} 251^{\text {-SET }}$ $(82.03 \pm 3.76 \%, \mathrm{P}=0.004$ and $124.01 \pm 8.91 \%, \mathrm{P}=0.008$, respectively), and in $\mathrm{U}^{2} 7 \mathrm{MG}^{-\mathrm{NC}}(7.67 \pm 3.88, \mathrm{P}=0.156 ; 11.07 \pm 6.80$, $\mathrm{P}=0.063)$ and $\mathrm{U} 251^{-\mathrm{NC}}(5.31 \pm 4.14, \mathrm{P}=0.076 ; 7.61 \pm 3.47, \mathrm{P}=0.147)$ cells compared the control groups (Fig. 6).

\section{Discussion}

In the present study, IHC determined that the protein expression level of SET was significantly upregulated in glioma tissues compared with normal brain tissues, indicating that SET may have an effect on the occurrence of GBM. In addition, the increased expression of SET was significantly correlated with a variety of important clinicopathological parameters, including gender, WHO grade II, III and IV classification, as well as moderate and low differentiation. SET expression was higher in men than that in women, suggesting that men may develop GBM more easily compared with women. In agreement, a previous study showed that the incidence rate of GBM is 1.6 times higher in men than in women (2). Although there is no statistical significance between SET expression and WHO 
grade I or well-differentiated cancer, the high malignancy of GBM and high expression of SET (Table IV) indicate that the expression level of SET may be associated with the malignant degree of cancer. In particular, SET expression may be positively involved in the progression of glioma. The current results suggest that the $S E T$ gene is associated with the occurrence of GBM and may be a potential carcinogenic factor in GBM. However, the detailed mechanism for SET upregulation in glioma has yet to be clarified.

In the current study, the rate of cell proliferation (Fig. 3) and migration (Fig. 4) significantly decreased after SET was inhibited, while the rate of cell apoptosis (Fig. 2) was significantly upregulated. A previous study revealed that SET is involved in regulating cell apoptosis, the cell cycle and cell migration (14), indicating that it may be a potential carcinogenic factor in GBM cells. Furthermore, the possible mechanism of SET involves the promotion of cell proliferation and migration, and the inhibition of GBM cell apoptosis.

In order to understand the detailed mechanism of SET in the occurrence of GBM, the present study focused on the correlation between SET, and Bcl-2, Bax and caspase-3 in U87MG and U251 cell lines. Anti-apoptotic Bcl-2, pro-apoptotic Bax and pro-apoptotic caspase- 3 have important roles in the occurrence, development and outcome of cancer. In particular, the relative ratios of the pro- and anti-apoptotic BCL2 family protein levels determine the sensitivity or resistance of cells to multiple apoptotic stimuli (20). Generally, there are two interconnected apoptotic pathways: Extrinsic and intrinsic mechanisms mediated by death receptors on the cell surface and mitochondria, respectively (21). This apoptotic mechanism is regulated by several proteins that belong to the BCL2 family, including anti-apoptotic (Bcl-2, Bcl-xl and Mcl-1) and pro-apoptotic (Bax, Bak, Bcl-xs, Bad and Bid) mediators that differentially effect mitochondrial homeostasis and cytochrome $c$ release (22). Bcl-2, which belongs to the BCL2 family, was initially identified in B cell malignancies and encodes an integral outer mitochondrial membrane protein that regulates the intrinsic mitochondrial apoptosis pathway; thus, Bcl-2 serves as an anti-apoptosis gene (23). Bax, a pro-apoptotic member of the Bcl-2 family of proteins, has the ability to form transmembrane pores large enough to allow cytochrome $c$ release, as well as the ability activate the mitochondrial permeability transition pore (24). Caspases, a family of cysteinyl aspartate-specific proteases, are best known as executioners of apoptotic cell death, and their activation are considered to be committed to inducing cell death (25); in particular, caspase-3, as one member of cysteinyl aspartate-specific proteases family, is known as a central effector of apoptosis (26). Furthermore, mitochondria have an important role in the intrinsic pathway of apoptosis, which is regulated by the Bcl-2 family of proteins through the pro-apoptotic protein BAX and the anti-apoptotic protein $\mathrm{Bcl}-2$. Mitochondria are involved in the production of reactive oxygen species production, the downregulation of Bcl-2, the upregulation of Bax, the release of cell death protein cytochrome $c$, and caspase-3 activation in various cell lines (27). In the present study, following inhibition of SET expression in two glioblastoma cell lines (U87MG and U251), the mRNA and protein expression level of SET were both significantly downregulated in $\mathrm{U} 87 \mathrm{MG}^{\text {-SET }}$ and $\mathrm{U} 251^{\text {-SET }}$ cells. Subsequently, mRNA and protein expression levels of Bcl-2,
Bax and caspase- 3 were detected in these two cell lines, and it was found that the expression of Bcl-2 significantly decreased, while the expression of Bax and caspase- 3 significantly increased compared with the two control groups, resulting in a lower Bcl-2/Bax ratio at the mRNA (Fig. 5) and protein (Fig. 6) expression level. Thus, the current data suggests that SET may regulate cell proliferation and apoptosis by upregulating $\mathrm{Bcl}-2$ gene expression and downregulating Bax and caspase- 3 genes, resulting in the development of cancer.

In conclusion, the current data suggests that SET may be a potential carcinogenic factor in GBM, and may regulate cell proliferation and apoptosis by upregulating $\mathrm{Bcl}-2$ gene expression, and downregulating Bax and caspase-3 expression. However, its detailed mechanism remains unknown. Previous studies have indicated that SET may be a downstream molecule that could be activated by the PI3K/Akt/mTOR signaling pathway in colorectal adenocarcinoma (28). Further research is required to determine whether SET regulates the expression of Bcl-2, Bax and caspase-3 through a series of complex regulatory mechanisms in this signaling pathway, resulting in the occurrence of GBM.

\section{Acknowledgements}

The current study was supported by a grant from the Chengdu Science and Technology Board (for research into the expression and mechanism of the SET gene in glioma).

\section{References}

1. Wu CX, Lin GS, Lin ZX, Zhang JD, Liu SY and Zhou CF: Peritumoral edema shown by MRI predicts poor clinical outcome in glioblastoma. World J Surg Oncol 13: 97, 2015.

2. Thakkar JP, Dolecek TA, Horbinski C, Ostrom QT, Lightner DD, Barnholtz-Sloan JS and Villano JL: Epidemiologic and molecular prognostic review of glioblastoma. Cancer Epidemiol Biomarkers Prev 23: 1985-1996, 2014.

3. Zhang L, Wang H, Ding $\mathrm{K}$ and Xu J: FTY720 induces autophagy-related apoptosis and necroptosis in human glioblastoma cells. Toxicol Lett 236: 43-59, 2015.

4. Koo S, Martin G and Toussaint LG: MicroRNA-145 promotes the phenotype of human glioblastoma cells selected for invasion. Anticancer Res 35: 3209-3215, 2015.

5. Chakrabarti M and Ray SK: Direct transfection of miR-137 mimics is more effective than DNA demethylation of miR-137 promoter to augment anti-tumor mechanisms of delphinidin in human glioblastoma U87MG and LN18 cells. Gene 573: 141-152, 2015.

6. Wang G, Wang J, Zhao H, Wang J and Tony To SS: The role of Myc and let-7a in glioblastoma, glucose metabolism and response to therapy. Arch Biochem Biophys 580: 84-92, 2015.

7. Cimino PJ, Bredemeyer A, Abel HJ and Duncavage EJ: A wide spectrum of EGFR mutations in glioblastoma is detected by a single clinical oncology targeted next-generation sequencing panel. Exp Mol Pathol 98: 568-573, 2015.

8. Yan J, Kong LY, Hu J, Gabrusiewicz K, Dibra D, Xia X, Heimberger $\mathrm{AB}$ and Li S: FGL2 as a multimodality regulator of Tumor-mediated immune suppression and therapeutic target in gliomas. J Natl Cancer Inst 107: pii.djv137, 2015.

9. Karetsou Z, Emmanouilidou A, Sanidas I, Liokatis S, Nikolakaki E, Politou AS and Papamarcaki T: Identification of distinct SET/TAF-Ibeta domains required for core histone binding and quantitative characterisation of the interaction. BMC Biochem 10: $10,2009$.

10. Irie A, Harada K, Araki N and Nishimura Y: Phosphorylation of SET protein at Ser171 by protein kinase D2 diminishes its inhibitory effect on protein phosphatase 2A. PLoS One 7: e51242, 2012.

11. Li M, Makkinje A and Damuni Z: The myeloid leukemia-associated protein SET Is a potent inhibitor of protein phosphatase 2A. J Biol Chem 271: 11059-11062, 1996. 
12. Almeida LO, Garcia CB, Matos-Silva FA, Curti C and Leopoldino AM: Accumulated SET protein up-regulates and interacts with hnRNPK, increasing its binding to nucleic acids, the Bcl-xS repression, and cellular proliferation. Biochem Biophys Res Commun 445: 196-202, 2014.

13. Xu Z, Yang W, Shi N, Gao Y, Teng M and Niu L: Cloning, purification, crystallization and preliminary X-ray crystallographic analysis of SET/TAF-Iß $\delta \mathrm{N}$ from Homo sapiens. Acta Crystallogr Sect F Struct Biol Cryst Commun 66: 926-928, 2010.

14. Lam BD, Anthony EC and Hordijk PL: Cytoplasmic targeting of the proto-oncogene SET promotes cell spreading and migration. FEBS Lett 587: 111-119, 2013.

15. Cristóbal I, Garcia-Orti L, Cirauqui C, Cortes-Lavaud X, García-Sánchez MA, Calasanz MJ and Odero MD: Overexpression of SET is a recurrent event associated with poor outcome and contributes to protein phosphatase $2 \mathrm{~A}$ inhibition in acute myeloid leukemia. Haematologica 97: 543-550, 2012.

16. Mukhopadhyay A, Tabanor K, Chaguturu R and Aldrich JV: Targeting inhibitor 2 of protein phosphatase $2 \mathrm{~A}$ as a therapeutic strategy for prostate cancer treatment. Cancer Biol Ther 14: 962-972, 2013.

17. Louis DN, Ohgaki H, Wiestler OD, Cavenee WK, Burger PC, Jouvet A, Scheithauer BW and Kleihues P: The 2007 WHO classification of tumours of the central nervous system. Acta Neuropathol 114: 97-109, 2007.

18. Gonzales MF: Grading of gliomas. J Clin Neurosci 4: 16-18, 1997.

19. Livak KJ and Schmittgen TD: Analysis of relative gene expression data using real-time quantitative PCR and the 2(-Delta Delta C(T)) method. Methods 25: 402-408. 2001.

20. Kontos CK,Fendri A,Khabir A, Mokdad-Gargouri R and Scorilas A: Quantitative expression analysis and prognostic significance of the BCL2-associated X gene in nasopharyngeal carcinoma: A retrospective cohort study. BMC Cancer 13: 293, 2013.
21. Manoochehri M, Karbasi A, Bandehpour M and Kazemi B: Down-regulation of BAX gene during carcinogenesis and acquisition of resistance to 5-FU in colorectal cancer. Pathol Oncol Res 20: 301-307, 2014

22. Croci DO, Cogno IS, Vittar NB, Salvatierra E, Trajtenberg F, Podhajcer OL, Osinaga E, Rabinovich GA and Rivarola VA: Silencing survivin gene expression promotes apoptosis of human breast cancer cells through a caspase-independent pathway. J Cell Biochem 105: 381-390, 2008.

23. Choi JE, Kang SH, Lee SJ and Bae YK: Prognostic significance of Bcl-2 expression in non-basal triple-negative breast cancer patients treated with anthracycline-based chemotherapy. Tumour Biol 35: 12255-12263, 2014

24. Gómez-Crisóstomo NP, López-Marure R, Zapata E, Zazueta C and Martinez-Abundis E: Bax induces cytochrome c release by multiple mechanisms in mitochondria from MCF7 cells. J Bioenerg Biomembr 45: 441-448, 2013.

25. Kavanagh E, Rodhe J, Burguillos MA, Venero JL and Joseph B: Regulation of caspase-3 processing by cIAP2 controls the switch between pro-inflammatory activation and cell death in microglia. Cell Death Dis 5: e1565, 2014.

26. Liu X, He Y, Li F, Huang Q, Kato TA, Hall RP and Li CY: caspase-3 promotes genetic instability and carcinogenesis. Mol Cell 58: 284-296, 2015.

27. Amar SK, Goyal S, Mujtaba SF, Dwivedi A, Kushwaha HN, Verma A, Chopra D, Chaturvedi RK and Ray RS: Role of type I \& type II reactions in DNA damage and activation of caspase 3 via mitochondrial pathway induced by photosensitized benzophenone. Toxicol Lett 235: 84-95, 2015.

28. Wen X, Zhu J, Dong L and Chen Y: The role of c2orf68 and PI3K/Akt/mTOR pathway in human colorectal cancer. Med Oncol 31: 92, 2014. 